\title{
DETERMINANTS OF THE USE OF BRI INTERNET BANKING ADOPTION: A STUDY ON POLITEKNIK NEGERI SEMARANG STUDENTS
}

\author{
CINDY MAYCHERLES* \\ MOH MUSLIKH \\ Politeknik Negeri Semarang \\ *cindymaycherles23@gmail.com
}

\begin{abstract}
The purposes of this research are to analyze and obtain empirical evidence on the effect of usefulness perception, ease perception, and risk perception toward the use of BRI Internet banking in Politeknik Negeri Semarang (Polines) students both simultaneously and partially. This research population was Polines students of all departments from 2017 to 2019 as customers of BRI Internet banking users with a sample of 87 respondents. The research used primary and secondary data. The data analysis model uses the Multiple Linear Regression Analysis Model, while the data analysis technique uses the F Test, t-Test, and $\mathrm{R}^{2}$ Test. The discussion analysis results show that the variables of usefulness perception and ease perception significantly affect the use of Internet banking. In contrast, the variable of risk perception has no significant impact on the use of Internet banking.
\end{abstract}

Keywords: Usefulness Perception, Ease Perception, Risk Perception, Use of Internet Banking

\section{INTRODUCTION}

In this sophisticated era, the banking industry must provide faster, easier, and more effective services than one of the biggest government-owned banks in Indonesia; PT Bank Rakyat Indonesia (Persero), Tbk (BRI). Besides providing excellent services, BRI must also maintain its market position amid rapidly growing technological advances. One of them is developing strategies to sustain customers through the Internet to support banking services called Internet banking.

Transactions made with Internet banking applications can be done through various media, such as computers and smartphones. The realization in the implementation in each media certainly has different characteristics and ways. Nevertheless, the use of Internet banking is undoubtedly intended for the benefits and conveniences of all customers in conducting banking transactions. For this, the student of Polines from 2017 to 2019 also included as customers of BRI Internet banking users.

Table 1 Number of Transactions Using BRI E-banking

\begin{tabular}{lrrr}
\hline \multirow{2}{*}{ E-banking Type } & \multicolumn{2}{c}{ Year } & \\
& $\begin{array}{c}\mathbf{2 0 1 8} \\
\text { (in billion) }\end{array}$ & $\begin{array}{c}\text { 2019 } \\
\text { (in billion) }\end{array}$ & Change \\
\hline ATM & $2.322,0$ & $2.118,3$ & $-8,8 \%$ \\
Mobile Banking & 317,6 & 370,5 & $16,7 \%$ \\
Internet Banking & 574,9 & $1.169,4$ & $103,4 \%$ \\
\hline
\end{tabular}

Source: ir-bri.com, 2020

Base on Table 1, it is known that over the last two years, the type of e-banking usage that is most in demand by BRI customers is Internet banking services compared to ATM and mobile banking. It is proved from the changing percentages in the number of transactions of Internet banking users of BRI, which increased to $103.4 \%$ compared to ATMs (decreased by $8.8 \%$ ) and mobile banking (increased by only $16.7 \%$ ). Based on the data, many customers in the field use the BRI Internet banking application service. It is also no exception 
with Polines students who become customers of BRI because the more significant the fundraising is done, the greater the use of Internet banking.

Table 2 Data of Polines Students from Various Departments as BRI Customers

\begin{tabular}{ccl}
\hline Year & $\begin{array}{c}\text { Number of Polines students } \\
\text { as BRI Customers }\end{array}$ & \multicolumn{1}{c}{ Source } \\
\hline 2017 & 204 & Google Drive BPM Polines \\
2018 & 146 & Polines.ac.id \\
2019 & 312 & Polines.ac.id \\
Total & 662 & Processed data \\
\hline
\end{tabular}

Source: Processed secondary data, 2020

Base on the pre-survey of Polines Student data as in the table above, of the 662 Polines' students as BRI customers, only a few use BRI Internet banking applications. Polines students prefer to make transactions conventionally by conducting transactions directly at the bank or at the ATM rather than using Internet banking. Meanwhile, only using an Internet banking application can all transactions be done anywhere and anytime as long as there are facilities to access it.

Internet banking uses Internet access to conduct transactions between customers and a bank (Antasaet al. al, 2013). Internet banking is beneficial for banks and easy to do for customers if used correctly and carefully to have no party loss. Therefore banks must know the driving factors for internet banking use so that customers are comfortable and safe in making transactions.

Usefulness perception is a level of individual trust that positively or negatively increases work rate through technology and information systems (Davis in Yudha and Isgiyarta, 2015). According to Agustina et al. (2018), usefulness perception affects the interest in using Internet banking. Based on Yudha and Isgiyarta (2015) research, showing the usefulness perception has a positive and significant effect on Internet banking adoption acceptance. It can be concluded that elements of usefulness such as services, effectiveness, and so on are proven to affect the usefulness perception to the customer's trust in using Internet banking (Putri and Fithrie, 2019). The variable of usefulness perception that involves the use of Internet banking, supported by previous research conducted by Agustina et al. (2018), Yudha and Isgiyarta (2015), Fadli and Fachruddin (2016), Putri and Fithrie (2019), and Laksana et al. (2015).

Ease perception is defined as the extent to which one believes that using technology will be free of effort (Oktabriantono et al., 2017). Based on the research conduct by Laksana et al. (2015), which is based on his opinion, the ease perception of use is the extent someone thinks that using technology does not require great effort, and it means that it is easy to use. The research on the analysis of the influence of perceived bank customers' on Internet banking adoption conducted by Yudha and Isgiyarta (2015) also showed that the perception of ease has a positive and significant influence on Internet banking adoption acceptance. Other research conducted by Putri and Fithrie (2019) on the influences of risk, usefulness, and ease of use on customers' trust in using Internet banking in Pekanbaru shows that the ease of using Internet banking has a positive relationship to the customer's trust in using Internet banking. The variable of ease perception that affects the use of Internet banking, supported by previous research conducted by Yudha and Isgiyarta (2015), Oktabriantono et al. (2017), Putri and Fithrie (2019), and Laksana et al. (2015).

Risk perception is a negative assumption from the customer of the uncertainties and consequences faced when someone conducts transactions online (Mauludiyah and Diana, 2018). According to Laksana et al. (2015) in his research mentioned that risk perception could be interpreted as a subjective perception or view of uncertainty and negative consequences in conducting an activity. According to the research conducted by Fadhli and Fachruddin (2016) and the research of Oktabriantono et al. (2017), it shows that risk perception has a negative effect on the use of Internet banking. It is also supported by Putri and Fithrie (2019) that the variable of risk perception has an effect on customer trust proven to affect risk perception to the customer's 
trust in the use of Internet banking. Risk perception has no positive effect and has a significant effect on Internet banking adoption (Yudha and Isgiyarta, 2015). The variable of risk perception that affects the use of Internet banking, supported by previous research conducted by Yudha and Isgiyarta (2015), Oktabriantono et al. (2017), Putri and Fithrie (2019), and Laksana et al. (2015).

Based on the business phenomena and research gap, this research's main problem is how to increase Internet banking user of PT Bank Rakyat Indonesia (Persero) Tbk, with the approach of usefulness perception, ease perception, and risk perception toward the students of Polines. So, it can be developed the frame of thought underlying this research. The research framework can be seen as follows:

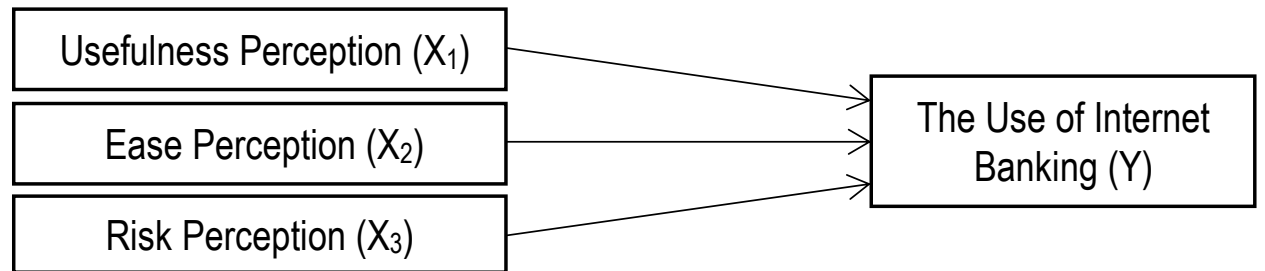

Source: Fadli and Fachruddin (2016), Putri and Fithrie (2019), Laksana et al. (2015), Oktabriantono et al. (2017), Yudha and Isgiyarta (2015), developed in this research

\section{Figure 1 Framework}

By the framework, the hypothesis in this research was submitted to prove whether there is a simultaneous or partial effect between the usefulness perception, ease perception, and risk perception toward the use of Internet banking of PT. Bank Rakyat Indonesia (Persero), Tbk (Case Study on the Students of Polines). The hypotheses presented in this research are as follows:

$\mathrm{H}_{1}$ : The variable of usefulness perception partially has a significant effect on the use of Internet banking of PT Bank Rakyat Indonesia (Persero), Tbk.

$\mathrm{H}_{2}$ : The variable of ease perception partially has a significant effect on the use of Internet banking of PT Bank Rakyat Indonesia (Persero), Tbk.

$\mathrm{H}_{3}$ : The variable of risk perception partially has a significant effect on the use of Internet banking of PT Bank

Rakyat Indonesia (Persero), Tbk.

\section{RESEARCH METHODS \\ Research Design}

The research design used in this research is causal applied research. Causality research tries to identify causal relationships or reasons for group or individual behavior or status as it is today. That cause can be found starting from the effect or starting from a dependent variable, and from the effect or that dependent variable, then searched causal or independent variables (Soewadji, 2012:25). Causality research and measuring the strength of relationships between two or more variables also show the relationship direction between independent and dependent variables. In short, causality research questioning causation problems (Kuncoro, 2001:16).

\section{Population and Samples}

This research population is all of Polines students from various departments formally registered as customers of BRI, both from the class of 2017 to 2019. They should have used BRI Internet banking application or have never used it, both male and female, namely 662 Students. Samples used in this research by Slovin formula as many as 87 respondents with criteria respondents ever actively conducts transactions.

\section{Data Analysis Method}

The data analysis method in this research used research instrument test (validity test and reliability test), normality test, classic assumption test (included multicollinearity tests, autocorrelation tests, and heteroscedasticity tests). Validity tests are used to measure whether or not each question item is valid on the 
questionnaire. The validity test also aims to measure whether each question item in the questionnaire can measure (Ghozali, 2018:51). Each question item can be said to be valid if the count (in SPSS output notified as corrected item-total correlation) is more than $r$ table with the significant level used is $(a)=0.05$. Reliability tests are used to measure a questionnaire as an indicator of a variable or construct (Ghozali, 2018:45). A questionnaire can be called reliable if a person's answer to each question item is consistent or stable over time.

Additionally, a variable or construct is reliable if Cronbach's Alpha value is 0.70 (Nunnally in Ghozali, 2018:46). Reliability testing in this research used the IBM Statistic Program for Social Science (SPSS) 20 program. The normality test aims to test whether, in regression models, disruptor variables or residuals have a normal distribution. If this test is violated, then the statistical test becomes invalid for a small number of samples. This research's normality test was conducted through 2 (two) approaches, namely histogram and PPlot charts and the Kolmogorov-Smirnov test. Kolmogorov-Smirnov test accepted when the sig value of the Kolmogorov-Smirnov test is more than 0,05. The multicollinearity test aims to test whether in the regression model there is a correlation between independent variables. Good research is research that does not occur multicollinearity between independent variables. It is known if the variance inflation factor (VIF) value less than ten and have a tolerance value of more than 0,10 . A good regression model is a regression that is free of autocorrelation.

The autocorrelation test aims to test whether linear regression models correlate with disruptive errors in the t period and errors in the (previous) $t-1$ period. If there is a correlation, then there is a problem of autocorrelation. Autocorrelation testing using Test Durbin-Watson (DW test) used to know autocorrelation. There is no Testing heteroscedasticity performed, to see the location of a particular pattern on the graph. The axis $X$ is a predicted $Y$, and the $X$-axis is residual (true $Y$ prediction $-Y$ ) studentized. If a particular pattern, such as existing dots (bullet points), forms a regular pattern (wavy, widening, then narrowing), heteroscedasticity has occurred. If there is no clear pattern, and the dots spread over and below the numbers 0 on the $Y$ axis, there is no heteroscedasticity (Ghozali, 2018). The heteroscedasticity test aims to test whether there is an inequality of residual variation of observation to another safety in a regression model. Good regression model shows no heteroscedasticity, hence, the residual variation of observation to another observation is fixed (homoscedasticity). In this research, the heteroscedasticity test conduct using Scatterplot Graphics Test and Glejser Test. Hypothesis test conducting in this study were Coefficient of Determination, Statistical Test $t$, and Statistical Test F. Once the significance value of statistical t-test and f-test below 0.05 or calculate t-test and F-test values are greater than the table, then the hypothesis is accepted and vice versa.

Variable operationalizations related to independent variables are including usefulness perception, ease perception, and risk perception. Those variables are affected by dependent variables of BRI's Internet banking use by Polines Students operated test in the field through their benchmarks or indicators, which can be seen as follows:

1. $X_{1}$. Usefulness Perception define as the degree to which one thinks that using a particular system will improve its performance (Davis in Yudha and Isgiyarta, 2015). According to Fadhli and Fachruddin (2016) stated, the usefulness perception is a level at which one thinks that using a system will improve performance and increase productivity and effectiveness levels. Measurement using scale Likert 1-4. According to Davis in Yudha and Isgiyarta (2015) mentions several indicators in the variable of Perception of Usefulness, among others, improve job performance, make work easier, and overall the technology used is perceived to be useful.

2. $X_{2}$. Ease perception, according to Fadhli and Fachruddin (2016), the perception of ease to the use of Internet banking is intended so that customers can use online banking services easily, be it easy to learn, easy to understand, easy to master, and easy to use. Perception of ease is a thinks in the decision-making process. If one thinks that the information system is easy to use, he will use it (Yudha and Isgiyarta, 2015). Measurement using scale Likert 1-4. According to Davis in Yudha and Isgiyarta (2015), the variable of Ease 
Perception mentions several indicators that affect it, among others easy to learn, flexible, and can control work.

3. $\mathrm{X}_{3}$. Risk Perception is a risky assumption that presents an individual's assessment of the possibilities associated with positive outcomes or negative of a transaction or situation (Fadhli and Fachruddin, 2016). According to Yudha and Isgiyarta (2015), risk perception is the level of user confidence in Internet banking services against the opportunity to lose users due to a lack of security and protection of the service system created. Perception of risk greatly affects confidence levels. The smaller the risk perception of an individual, the greater the level of trust, and vice versa. If the risk increases from information to product purchase decisions (transaction), risks are associated with trust (Dowling and Staelin in Yudha and Isgiyarta, 2015). Measurement using scale Likert 1-4. According to Fadhli and Fachruddin (2016), several indicators affect the variable of risk perception, among others security, identity confidentiality guarantee, and transaction guarantee.

4. Y. The Use of Internet Banking. According to Fadhli and Fachruddin (2016), Internet banking uses the Internet as a long-distance extension channel to deliver banking services. According to Nurastuti in Fadhli and Fachruddin (2016), Internet banking is one of banks' services through the Internet that allows customers to obtain banking services and services such as obtaining information and conducting banking transactions. Measurement using scale likLikert4. The following are variable indicators of the use of Internet Banking according to Fadhli and Fachruddin (2016), among others consistent, transaction diversity, and appropriate.

The data analysis model used in this research is to use multiple linear regression analysis. Multiple linear regression analysis aims to calculate an event change (independent variable) on other events (dependent variables). It is converted to test the effect of usefulness perception, ease perception, and risk perception on BRl's Internet banking usage in Polines Students. The following are the equations of linear regression analysis models in this research, namely:

$Y=a+b_{1} X_{1}+b_{2} X_{2}+b_{3} X_{3}+e$

Descriptions:

$\mathrm{Y} \quad=$ The use of Internet banking

a $\quad=$ Constants

$\mathrm{b}_{1} \quad=$ Regression coefficient for each $\mathrm{X}_{1}$

$b_{2} \quad=$ Regression coefficient for each $X_{2}$

$b_{3} \quad=$ Regression coefficient for each $X_{3}$

$X_{1} \quad=$ Usefulness Perception

$\mathrm{X}_{2} \quad=$ Ease Perception

$\mathrm{X}_{3} \quad=$ Risk Perception

e $\quad=$ Residual error (error)

\section{RESULTS AND DISCUSSIONS}

Based on table 3, it can be seen that the calculation results of each indicator on each variable have tcount $>$ r-table. Therefore, it can be concluded that each question item and the data obtained from each question item on the questionnaire are valid and usable.

\section{Table 3 Validity Test Results}

$\begin{array}{lllll}\text { Variable } & \text { Indicator } & r_{\text {count }} & r_{\text {tables }} & \text { Description }\end{array}$




\begin{tabular}{lllll}
\hline Perception of & X1.1 & 0,614 & 0,178 & VALID \\
Usefulness (X1) & X1.2 & 0,507 & 0,178 & VALID \\
& X1.3 & 0,473 & 0,178 & VALID \\
Perception of Ease & X2.1 & 0,548 & 0,178 & VALID \\
(X2) & X2.2 & 0,478 & 0,178 & VALID \\
& X2.3 & 0,614 & 0,178 & VALID \\
Perception of Risk & X3.1 & 0,377 & 0,178 & VALID \\
(X3) & X3.2 & 0,334 & 0,178 & VALID \\
& X3.3 & 0,433 & 0,178 & VALID \\
The Use of Internet & Y1 & 0,437 & 0,178 & VALID \\
Banking $(Y)$ & Y2 & 0,408 & 0,178 & VALID \\
& Y3 & 0,458 & 0,178 & VALID \\
\hline
\end{tabular}

Source: Primary data processed, 2020

Table 4 Reliability Test Results

\begin{tabular}{|c|c|c|c|c|}
\hline \multicolumn{2}{|l|}{ Reliability Statistics } & & & \\
\hline $\begin{array}{l}\text { Cronbach's Alpha } \\
.818\end{array}$ & $\begin{array}{c}\text { N of Items } \\
12\end{array}$ & & & \\
\hline \multirow[b]{2}{*}{ Variable } & \multirow[b]{2}{*}{ Indicator } & \multicolumn{3}{|c|}{ Statistic Test } \\
\hline & & $\begin{array}{l}\text { Cronbach's Alpha } \\
\text { if Item Deleted }\end{array}$ & $\begin{array}{l}\text { Standard } \\
\text { Minimum }\end{array}$ & Description \\
\hline Perception of & $\mathrm{X} 1.1$ & 0,793 & 0,70 & RELIABLE \\
\hline \multirow[t]{2}{*}{ Usefulness (X1) } & $\mathrm{X} 1.2$ & 0,802 & 0,70 & RELIABLE \\
\hline & X1.3 & 0,805 & 0,70 & RELIABLE \\
\hline Perception of Ease & $X 2.1$ & 0,798 & 0,70 & RELIABLE \\
\hline \multirow[t]{2}{*}{$(X 2)$} & $X 2.2$ & 0,804 & 0,70 & RELIABLE \\
\hline & $X 2.3$ & 0,793 & 0,70 & RELIABLE \\
\hline Perception of Risk & X3.1 & 0,813 & 0,70 & RELIABLE \\
\hline \multirow[t]{2}{*}{ (X3) } & X3.2 & 0,816 & 0,70 & RELIABLE \\
\hline & X3.3 & 0,811 & 0,70 & RELIABLE \\
\hline The Use of Internet & Y1 & 0,809 & 0,70 & RELIABLE \\
\hline \multirow[t]{2}{*}{ Banking $(Y)$} & Y2 & 0,810 & 0,70 & RELIABLE \\
\hline & Y3 & 0,807 & 0,70 & RELIABLE \\
\hline
\end{tabular}

Source: Processed primary data, 2020

Based on the table of reliability test results above, the test on each questionnaire question item in this research is entirely obtained reliable results. As Cronbach's Alpha (a) results> 0.70 on each question item, it can be said that the measuring instruments in this research are reliable.

The normality test aims to test whether, in regression models, disruptor variables or residuals have a normal distribution. If this test is violated, then the statistical test becomes invalid for a small number of samples. The normality test in this research was conducted through 2 (two) approaches, namely histogram and P-Plot charts and the Kolmogorov-Smirnov test. The following are the results of the normality test using the histogram approach, namely: 


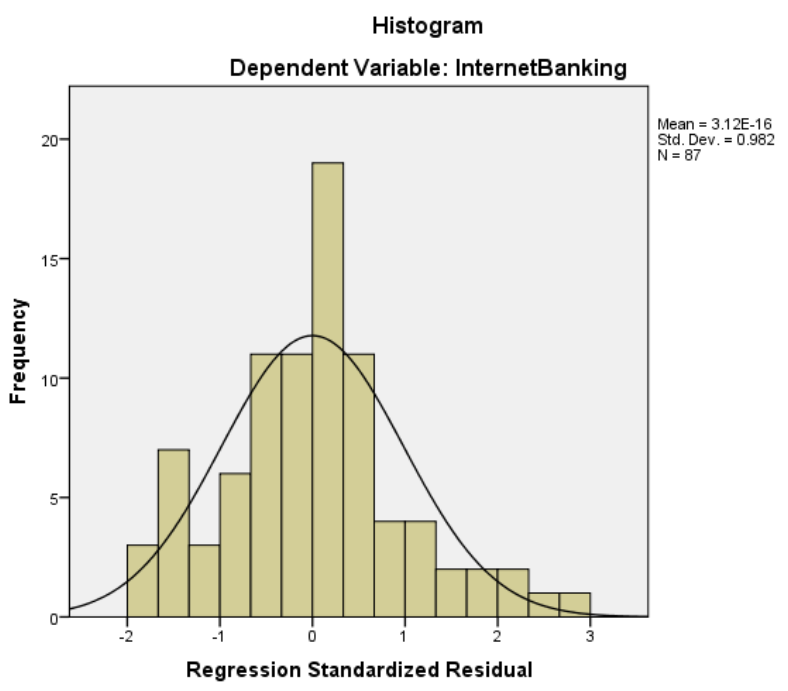

Source: Primary data processed, 2020

Figure 2 Histogram Graphics

Based on Figure 2, it is known that histogram graphics provide a near-normal distribution pattern. This is because the histogram graphics still appear to lean to the left. But by looking at histogram graphics alone, this can be misleading, especially for a small number of samples. A more reliable method is with a normal probability plot that compares cumulative distribution and normal distribution. The following are the results of testing normality with normal probability plots, as follows:

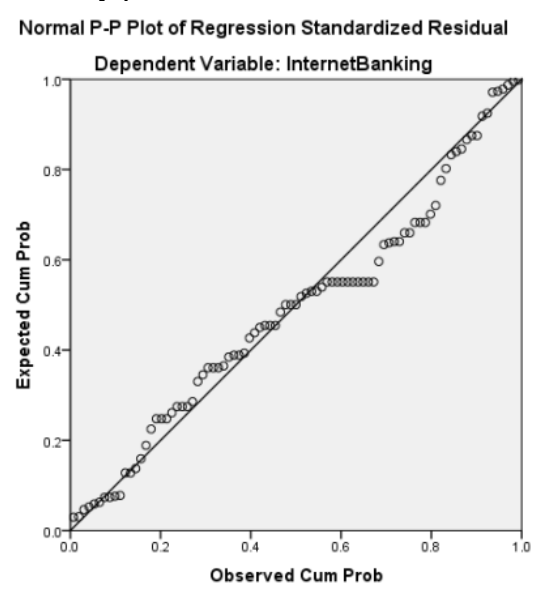

Source: Primary data processed, 2020

Figure 3 Normal Probability Plot

Based on figure 3 , it can be seen that the normal probability plot graphic shows the dots spreading around the diagonal line and following the direction of the diagonal line. Suppose the line describing the actual data will follow its diagonal line. In that case, the distributed data is normal, so it can be said that the regression model meets the assumption of normality.

The following is a normality test table with the Kolmogorov-Smirnov Test (K-S) to strengthen the normality test, whether the residual value is based on normal. If the value is significant $>0.05$, then residual is said to be distributed normally. 
Table 5 Kolmogorov-Smirnov Non-Parametric Statistical Test (K-S)

\begin{tabular}{llr}
\hline \multicolumn{3}{c}{ One-Sample Kolmogorov-Smirnov Test } \\
\hline $\mathrm{N}$ & & Unstandardized Residual \\
Normal Parametersa,b & Mean & 87 \\
& Std. Deviation & $0 \mathrm{E}-7$ \\
& Absolute & .77644349 \\
Most Extreme Differences & Positive & .126 \\
& Negative & .126 \\
Kolmogorov-Smirnov Z & & -.060 \\
Asymp. Sig. (2-tailed) & 1.178 \\
a. Test distribution is Normal. & .125 \\
b. Calculated from data. & \\
\hline
\end{tabular}

Source: Primary data processed, 2020

Based on Table 5 , it can be noted that the asymptotic significance value of 0.125 is greater than 0.05 . This evidence suggests that in this research, variable disruptors or residuals distributed normally, so that regression models are worth using to conduct research

Table 6 Multiple Linear Regression Analysis

\begin{tabular}{|c|c|c|c|c|c|c|}
\hline \multirow{3}{*}{ Model } & \multicolumn{6}{|c|}{ Coefficients } \\
\hline & & \multicolumn{2}{|c|}{ Unstandardized Coefficients } & Standardized & $t$ & $\mathrm{Si}$ \\
\hline & & B & Std. Error & Beta & & \\
\hline \multirow{5}{*}{1} & (Constant) & 4.334 & .848 & & 5.112 & .000 \\
\hline & Manfaat & .192 & .089 & .246 & 2.153 & .034 \\
\hline & Kemudahan & .224 & .081 & .313 & 2.763 & .007 \\
\hline & Risiko & .091 & .070 & .126 & 1.307 & .195 \\
\hline & \multicolumn{6}{|c|}{ Dependent Variable: Internet Banking } \\
\hline
\end{tabular}

Source: primary data processed, 2020

Based on this, there can be multiple linear regression equations as follows:

The Use of Internet Banking $=4.334+0.192$ Usefulness Perception +0.224 Ease Perception

The above equations are interpreted as follows:

\section{+0.091 Risk Perception + e}

\section{Constant $=4.334$}

The constant value of the multiple linear regression equation above is 4.334 with a positive sign. It means that the dependent variable, namely the use of Internet banking, will have a value of 4.334 if the variables of usefulness perception, ease perception, and risk perception is non-existent or zero (0).

2. $X_{1}=0.192$

The $X_{1}$ in that Regression means usefulness perception. The variable of usefulness perception has a regression coefficient value of 0.192 with a positive sign (+). It means that if there is an increase in the value of ease perception by one unit, it will cause an increase in the use of Internet banking by 0.192 units, assuming the other independent variables are considered non-existent or zero (0). So the value of the use of Internet banking is 4.526 .

\section{3. $X_{2}=0.224$}


The $X_{2}$ in that Regression means ease perception. The ease perception variable has a regression coefficient value of 0.224 with a positive sign (+). It means that if there is an increase in the value of ease perception by one unit, it will cause an increase the use of Internet banking by 0.224 units, assuming the other independent variables are considered non-existent or zero (0). So the value of the use of Internet banking is 4.558 .

\section{4. $\mathrm{X}_{3}=0.091$}

The $X_{3}$ in that Regression means risk perception. The variable of risk perception has a regression coefficient value of 0.091 with a positive sign (+). It means that if there is an increase in the value of risk perception by one unit, it will cause an increase in the use of Internet banking by 0.091 units, assuming the other independent variables are considered non-existent or zero (0). So the value of the use of Internet banking is 4.425 .

Table $7 \mathrm{~F}$ statistical Test

\begin{tabular}{|c|c|c|c|c|c|c|}
\hline \multicolumn{7}{|c|}{ ANOVA } \\
\hline \multicolumn{2}{|r|}{ Model } & $\begin{array}{l}\text { Sum of } \\
\text { Squares }\end{array}$ & $d f$ & Mean Square & $\mathrm{F}$ & Sig. \\
\hline \multirow{3}{*}{1} & Regression & 22.590 & 3 & 7.530 & 12.055 & $.000^{b}$ \\
\hline & Residual & 51.846 & 83 & .625 & & \\
\hline & Total & 74.437 & 86 & & & \\
\hline & $\begin{array}{l}\text { ndent Variak } \\
\text { ctors: (Cons }\end{array}$ & $\begin{array}{l}\text { ternetBanking } \\
\text { Risiko, Kemu }\end{array}$ & n, Mar & & & \\
\hline
\end{tabular}

Source: Primary data processed, 2020

Based on that table generated $F_{\text {count }}=12,055>F_{\text {table }}=2,713$ or signification rate $=0.000$ smaller than $5 \%$ or 0.05 . It means that there is a significant effect between the variables of usefulness perception, ease perception, and risk perception toward the use of Internet banking. Based on the identification of the analysis of the above data can be concluded that the model in this research is fit.

Table $8 \mathrm{t}$ Statistical Test

\begin{tabular}{|c|c|c|c|c|c|c|}
\hline & & & Coefficients & & & \\
\hline & Model & Unstandardize & Coefficients & $\begin{array}{l}\text { Standardized } \\
\text { Coefficients }\end{array}$ & $t$ & Sia \\
\hline & & $B$ & Std. Error & Beta & & \\
\hline & (Constant) & 4.334 & .848 & & 5.112 & .000 \\
\hline 1 & Manfaat & .192 & .089 & .246 & 2.153 & .034 \\
\hline 1 & Kemudahan & .224 & .081 & .313 & 2.763 & .007 \\
\hline & Risiko & .091 & .070 & .126 & 1.307 & .195 \\
\hline & dent $t$ & t Bank & & & & \\
\hline
\end{tabular}

Source: Primary data processed, 2020

Based on that table, it can be explained that:

1. The value of $t_{\text {count }}$ for the variable of usefulness perception (in the table written Manfaat) of $2.153>$ $t_{\text {table }}=1,989$ or significance $=0.034<0.05$, which means there is a significant effect between a variable of usefulness perception partially toward the use of Internet banking. It means hypothesis 1 in this research states that "Assumed the variable of usefulness perception partially has a significant effect toward the use of Internet banking of PT Bank Rakyat Indonesia (Persero), Tbk. (Case Study on the Students of Politeknik Negeri Semarang)", stated accepted.

2. The value of $t_{\text {count }}$ for the variable of ease perception (in the table written Kemudahan) of $2.763>t_{\text {table }}$ $=1,989$ or significance $=0.007>0.05$, which means there is a significant effect between the variable of ease perception partially toward the use of Internet banking. It means hypothesis 2 in this research 
states that "Assumed the variable of ease perception partially has a significant effect toward the use of Internet banking of PT Bank Rakyat Indonesia (Persero), Tbk. (Case Study on the Students of Politeknik Negeri Semarang)", stated accepted.

3. The value of $t_{\text {count }}$ for the variable of risk perception (in the table written Risiko) of $1,307<t_{\text {table }}=1,989$ or significance $=0.195>0.05$, which means there is no significant effect between the variable of risk perception partially toward the use of Internet banking. It means hypothesis 3 in this research which states that "Assumed the variable of risk perception partially has a significant effect toward the use of Internet banking of PT Bank Rakyat Indonesia (Persero), Tbk (Case Study on the Students of Politeknik Negeri Semarang)," stated rejected.

Table 9 Determination Coefficient Test $\left(\mathbf{R}^{2}\right)$

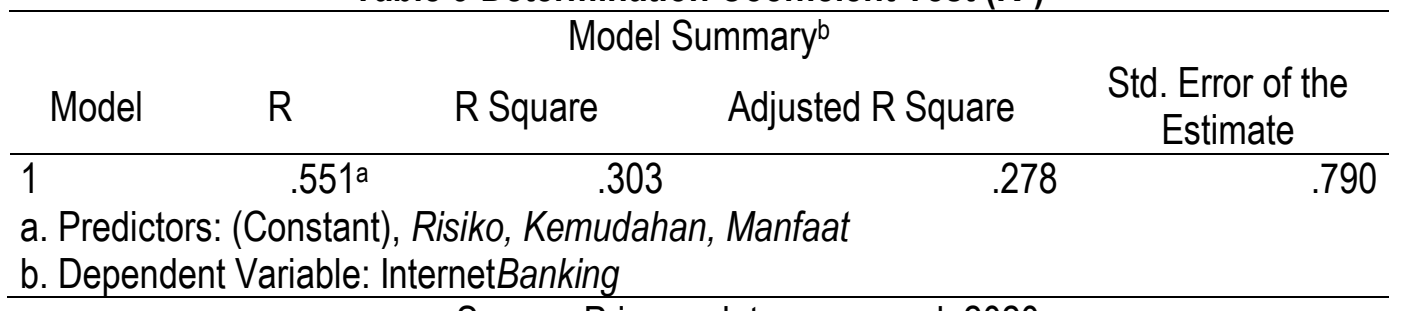

Source: Primary data processed, 2020

Based on the table shows that an Adjusted R Square value of 0.278 or $27.8 \%$. It means that the variable of usefulness perception, ease perception, and risk perception contributed toward the use of Internet banking by $27.8 \%$. In comparison, the remaining $72.2 \%$ was affected by other variables not studied in this research.

Based on the tests that have been conducted on hypothesis 1 using the $F$ test, the results show that usefulness perception, ease perception, and risk perception simultaneously have a positive and significant effect on Internet banking use. Based on the results of the $\mathrm{R}^{2}$ test, it is seen that the value of the determination coefficient (R2) in Table 4.15 is 0.278 . It showed that the variables of usefulness perception, ease perception, and risk perception accounted for $27.8 \%$ of Internet banking use, and the remaining $72.2 \%$ were affected by other variables not studied in the research. Based on hypothesis test 2 using statistical test $t$, the results showed that the variables of usefulness perception partially had a positive and significant effect on the use of Internet banking. The results of this research are in line with previous research conducted by Laksana et al. (2015), Putri and Fithrie (2019), Fadhli and Fachruddin (2016), Yudha and Isgiyarta (2015), and Oktabriantono et al. (2017). The finding that the usefulness perception variables and usefulness perception variable are improving job performance makes work easier. Overall, the technology used is perceived to be useful, having a positive and significant effect on the use of BRI Internet banking on Polines Students. However, this research results are different from the research conducted by Rakhmawati and Isharijadi (2013). Research conducted by Rakhmawati and Isharijadi (2013) stated that the usefulness perception does not positively affect the interest in the use of Internet banking. Based on hypothesis test 3 using statistical test $t$, the results show that the variable of ease perception partially had positive and significant effects on internet banking use. The results of this research are in line with previous research conducted by Oktabriantono et al. (2017), Yudha and Isgiyarta (2015), Fadhli and Fachruddin (2016), Putri and Fithrie (2019), and Laksana et al. (2015). Based on this, the finding that variable of ease perception with indicators of easy to learn, flexible, and can control work, has a positive and significant effect toward the use of BRI Internet banking on Polines Students. However, this research results are different from the research conducted by Ahmad and Pambudi (2014). Research conducted by Ahmad and Pambudi (2014) stated that the variable of ease perception does not affect customers' re-interest using Internet banking services. Based on hypothesis test 4 using statistical test $t$, the results showed that the variable of risk perception partially had no a positive and insignificant effect 
on Internet banking use. The results of this research are in line with previous research conducted by Yudha and Isgiyarta (2015), Fadhli and Fachruddin (2016), and Oktabriantono et al. (2017). Based on this, the finding that the variable of risk perception with indicators of security, identity confidentiality guarantee, and transaction guarantee does not have a positive and insignificant effect on the use of BRI's Internet banking on Polines Students. It was originally thought that the variable of risk perception had a significant effect on the use of Internet banking. It is based on a theory put forward by Murfi and Suripto (2020), which states that partially the variable of risk perception has a significant effect on students' interest in using Internet banking. However, this research shows that the variable of perception of risk has a positive and insignificant effect on the use of Internet banking. It indicates that the higher the risk has no effect on Internet banking use on BRI customers of Internet banking users, especially among Polines students. Several factors concerning BRI customers of Internet banking users, especially in Polines students, have never experienced the risk of using Internet banking such as hacker cases, inappropriate transaction errors, and customer data misused by bank employees allegedly making risk variables do not affect Internet banking usage.

\section{CONCLUSIONS AND SUGGESTIONS Conclusions}

Based on the main research problem, can be concluded that the variable of usefulness perception, ease perception, and risk perception simultaneously have a significant effect toward the use of Internet banking. Partially the variables of usefulness perception and ease perception have a significant effect on the use of Internet banking. In contrast, the variable of risk perception has no significant effect on the use of Internet banking.

\section{Limitations}

This Research has the following limitations:

1. Limited independent variables only tested 3 (three) independent variables (usefulness perception, ease perception, and risk perception), resulting in an effect toward the use of Internet banking of $27.8 \%$. In contrast, the other $72.2 \%$ were affected by other variables not studied in this research.

2. This research sample is limited to only 87 customers of BRI Internet banking users, especially Polines students.

This research results are still not perfect due to various constraints such as energy, cost, and time that are not intensive in researching in the pandemic period as it is today.

\section{Suggestions}

The suggestions for the future research agendas as follow:

1. In further research can use additional other independent variables such as the perception of security and perception of trust and other dependent variables such as interest in re-use of Internet banking applications or satisfaction of using Internet banking applications.

2. Samples for further research can be expanded again by using sample determination methods other than the Slovin formula so that it is expected to get actual answers.

\section{BIBLIOGRAPHY:}

Antasari, A. S. et al. (2013). Pengaruh Penggunaan Internet Banking Terhadap Kepuasan Nasabah (Studi Kasus pada PT Bank Rakyat Indonesia (Persero), Tbk Cabang Bontang). Jurnal Administrasi Bisnis (JAB), 1(2).

Fadhli, M. dan Fachruddin, R. (2016). Pengaruh Persepsi Nasabah Atas Risiko, Kepercayaan, Manfaat, Dan Kemudahan Penggunaan Terhadap Penggunaan Intenet Banking (Studi Empiris Pada 
Nasabah Bank Umum Di Kota Banda Aceh). Jurnal IImiah Mahasiswa Ekonomi Akuntansi (JIMEKA), 1(2), 264-276.

Ferdinand, A. (2014). Metode Penelitian Manajemen Pedoman Penelitian Untuk Penelitian, Skripsi, Tesis, Dan Disertasi IImu Manajemen. Semarang: Badan Penerbit Universitas Diponegoro.

Ghozali, I. (2018). Aplikasi Analisis Multivariate dengan Program SPSS IBM SPSS 25 Edisi 9. Semarang: Badan Penerbit Universitas Diponegoro.

(2006). Aplikasi Analisis Multivariate dengan Program SPSS. Semarang: Badan Penerbit Universitas Diponegoro.

Kholid, F. I. dan Soemarso, E. D. (2018). Analisis Pengaruh Keamanan, Kemudahan Penggunaan, Kepercayaan Nasabah Dan Kebermanfaatan Terhadap Minat Menggunakan E-Banking Pada PT Bank BNI Syariah KCP Magelang. Jurnal Sains Ekonomi dan Perbankan Syariah. 8(2).

Kuncoro, M. (2001). Metode Kuantitatif Teori Dan Aplikasi Untuk Bisnis Dan Ekonomi. Yogyakarta: Unit Penerbit dan Percetakan AMP YKPN.

Laksana, G. B. et al. (2015). Pengaruh Persepsi Kemanfaatan, Persepsi Kemudahan Penggunaan, Persepsi Resiko Dan Persepsi Kesesuaian Terhadap Minat Menggunakan Mobile Banking (Studi Pada Nasabah Bank Rakyat Indonesia (BRI) Kantor Cabang Rembang, Jawa Tengah). Jurnal Administrasi Bisnis, 26(2).

Mauludiyah, A. L. dan Diana, N. (2018). Pengaruh Kepercayaan, Keamanan, Persepsi Risiko, Serta Kesadaran Nasabah Terhadap Adopsi E-Banking Di Bank BRI Kantor Cabang Kas Universitas Islam Malang. Fakultas Ekonomi Dan Bisnis Universitas Islam Malang (E-JRA), 7(7).

Murfi, R. dan Suripto, T. (2020). Analisa Minat Mahasiswa terhadap Penggunaan Layanan Internet Banking Bank BNI Syariah. Jurnal Ekonomi Syariah Indonesia, 10(1).

Oktabriantono, A. P. et al. (2017). Pengaruh Persepsi Kebermanfaatan, Persepsi Kemudahan Penggunaan, Keamanan, Dan Persepsi Risiko Terhadap Penggunaan E-Banking Pada Mahasiswa S1 Fakultas Ekonomi Univeritas Pendidikan Ganesha. E-Journal S1 Ak Universitas Pendidikan Ganesha Jurusan Akuntansi Program S1, 8(2).

Pambudi, A., dan Setiyo, B. (2014). Pengaruh Persepsi Manfaat, Persepsi Kemudahan, Keamanan dan Ketersediaan Fitur Terhadap Minat Ulang Nasabah Bank dalam Menggunakan Internet Banking (Studi pada Program Layanan Internet Banking BRI). Jurnal Studi Manajemen, 8(1).

Putri, D. L. dan Fithrie, S. (2019). Pengaruh Risiko, Manfaat Dan Kemudahan Penggunaan Terhadap Kepercayaan Nasabah Dalam Menggunakan Internet Banking Di Pekanbaru (Studi Kasus Pada Nasabah Bank Mandiri). Ikraith Ekonomika, 2(2).

PT BANK RAKYAT INDONESIA (PERSERO) Tbk. (2020). FY'2019 - Financial Update Presentation. https://www.ir-bri.com/misc/PS/2019/FY-2019-BRI-Financial-Update.pdf

Rakhmawati, S. I. (2013). Pengaruh Kepercayaan, Persepsi Kegunaan, dan Persepsi Kenyamanan Terhadap Minat Penggunaan Sistem Internet Banking pada Nasabah Bank Muamalat Cabang Pembantu Madiun. Jurnal Akuntansi dan Pendidikan, 2(2).

Sarwono, J. (2012). Metode Riset Skripsi: Pendekatan Kuantitatif (Menggunakan Prosedur SPSS). Jakarta: Percetakan PT Gramedia.

Soewadji, J. (2012). Pengantar Metodologi Penelitian. Jakarta: Mitra Wacana Media.

Sugiyono. (2015). Metode Penelitian Kuantitatif, Kualitatif, Dan R\&D. Bandung: Alfabeta CV.

Sujarweni, V. W. (2015). SPSS Untuk Penelitian. Yogyakarta: Penerbit Pustaka Baru Press.

. (2018). Metodologi Penelitian Bisnis Dan Ekonomi Pendekatan Kuantitatif. Yogyakarta: Pustaka Baru Press.

Sulistyorini, U. S. (2017). Metode Penelitian Analisis Kausal-Regresi. Semarang: Politeknik Negeri Semarang. 
Wibowo, A. E. (2012). Aplikasi Praktis SPSS dalam Penelitian. Yogyakarta: Penerbit Gava Media Yuandari, E dan Rahman, R. T. (2014). Metodologi Penelitian Dan Statistik. Bogor: Penerbit IN MEDIA Yudha, H. N. dan Isgiyarta, J. (2015). Analisis Pengaruh Persepsi Nasabah Bank Terhadap Internet Banking Adoption (Studi Pada Nasabah Perbankan yang Menggunakan Internet Banking di Kota Surabaya). Diponegoro Journal of Accounting, 4(4), 2337-3806. 